TEME, г. XLI, бр. 2, април - јун 2017, стр. 407-423

Претходно саопштење

DOI: $10.22190 /$ TEME1702407M

Примљено: 28. 5. 2016.

Ревидирана верзија: 14. 3. 2017.

Одобрено за штампу: 15. 6. 2017.

\title{
СРПСКИ ЦРКВЕНИ ЧАСОПИСИ О ОРГАНИЗАЦИЈИ, ШИРЕЊУ И ДЈЕЛОВАЊУ КОМУНИЗМА У КРАЉЕВИНИ СХС/ЈУГОСЛАВИЈИ (1920-1940)
}

\author{
Небојша Малешевић \\ Универзитет у Београду, Православни богословски факултет, \\ Београд, Србија \\ nebojsa_bill@live.com
}

\begin{abstract}
Апстракт
Примарна интенција рада јесте приказ организације, ширења и дјеловања комунизма пропраћена у српским црквеним часописима између 1920. и 1940. године у Краљевини Срба, Хрвата и Словенаца / Југославији. Аутор ће, анализирајући све доступне и релевантне црквене часописе из тог периода, приказати како је српска црквена штампа реаговала на појаву комунизма. Посебна пажња биће посвећена организацији, ширењу и (тајном) дјеловању комуниста од оснивања Комунистичке партије Југославије (КПЈ) и Савеза комунистичке омладине Југославије (СКОЈ), па све до почетка Другог свјетског рата. Комунизам, тада нова политичка филозофија. Настао је као чедо социјализма насупрот капитализму, полако дошао на сцену нове државе основане послије Првог свјетског рата. Користећи још младу, економски ослабљењу, може се рећи и недовољно организовану мултинационалну и мултирелигиозну краљевину, комунизам је полако, великом дисциплином својих присталица и добром организацијом ширио своје поље дјеловања. У раду ће управо бити ријечи о томе да ли је и како српска црквена штампа препознала дјеловање и ширење нове политичке мисли, како ју је коментарисала, те шта је савјетовала да би се даље ширење зауставило.
\end{abstract}

Кључне речи: комунизам, српски црквени часописи, Краљевина

СХС/Југославија.

\section{SERBIAN CHURCH MAGAZINES ABOUT THE ORGANIZATION OF COMMUNISM, EXPANSION AND OPERATION IN THE KINGDOM OF SHS / YUGOSLAVIA (1920-1940)}

\footnotetext{
Abstract

The primary intention of the paper is to show Communism organization, expansion and operation followed by Serbian Church magazines between 1920 and 1940 in the
} 
Kingdom of Serbs, Croats and Slovenes / Yugoslavia. The author, will by analyzing all available and the relevant church newspapers from that period show how the Serbian Church magazines reacted to Communism. Special attention will be paid to the organization, expansion and (secret) action of the Communists since the founding of the Communist Party of Yugoslavia (KPY) and the Young Communist League of Yugoslavia (SKOJ) until the beginning of World War II. Communism, at the time, was a new political philosophy which was developed as a child of socialism versus capitalism. Communism slowly came to the scene of the new state which was founded after World War I. Communism using the still young, economically weaken, and we can say insufficiently organized, multinational and multi-religious Kingdom, slowly, with a great discipline of his supporters and good organization expanded its field of action. In this paper, we will talk about it, whether, and how, Serbian church magazine recognized organization and expansion of the new political thinking and how it commented on itture.

Key words: communism, Serbian Church magazines, the Kingdom of SHS / Yugoslavia.

\section{УВОД}

У тешким послијератним приликама Српска православна црква смогла је снаге и искористила штампу и њену огромну важност коју је имала у модерном друштву. ${ }^{1}$ Будући да је виша јерархија била заузе-

\footnotetext{
${ }^{1}$ Прегледали смо све сачуване и доступне црквене часописе од 1920. до 1940. године. Међу њима су се посебно истицали:

- Весник, покренут у Београду 1919. године од Свештеничког удружења бивше Краљевине Србије, представника Удружења свештенства Босне и Херцеговине, Карловачке митрополије и Црне Горе;

- Гласник Српске православне патријаршије, покренут у Београду 1920. године. Први број Гласника имао је поднаслов „Службени лист уједињене Српске православне патријаршије”, док од петог броја поднаслов гласи „Службени лист Српске православне патријаршије", све до 1939. године;

- Глас Цркве, покренут у Шапцу септембра 1923. године као орган свештенства епархије шабачке;

- Пастир, лист ученика Богословије у Призрену. Покренут је 1925, а трајао до 1927. године, када је угашен због материјалне оскудице;

- Богословље, часопис Православног богословског факултета покренут 1926. године;

- Светосавље, часопис студената Православног богословског факултета. Покренут је 1932. године;

- Духовна стража, излази од 1928. до 1940. године као власништво „Монашког удружења Српске православне цркве";

- Хришћанска мисао, покренут у Београду 1935. године од Удружења универзитетски образованих богослова;

- Хришћанско дело, покренуто у Скопљу 1935. године. Излазило је у двомјесечним свескама од по 80 страна све до 1941. године;

- Хришћански живот, „мјесечни часопис за хришћанску културу и црквени живот" излазио у Сремским Карловцима од 1922. до 1931. године.
} 
та провођењем црквеног јединства, нижа јерархија и поједини добро образовани чланови Цркве узели су на себе терет, те својом великом жељом и вољом кренули у нормализовање црквених прилика и вјерскоморалног живота, управо путем штампе (Цисарж, 1986, стр. 141-142).

Већ од 1919. године, комунисти, користећи оскудицу, економске проблеме, несређеност политичких и привредних прилика у земљи, почињу да дјелују на више фронтова. То се највише осјећа међу студентима, гдје због постојећег назадовољства комунистичка мисао наилази на плодно тле.

Цјелокупна партијска дјелатност и живот у Југославији биће прожети снажним агитационо-пропагандним радом, којим је партија наметала нови систем вриједности, своју политику и идеологију марксизма. Унутар партијске организације требало је правилно идеолошко-политички усмјерити чланство, а на ширем нивоу требало је „преваспитати масе”, посебно омладину, у складу с партијском политиком и идеологијом и борити се против непријатељских утицаја у култури, просвјети, науци и умјетности.

То су осјетили потписници радова које смо анализирали и због тога су често критиковали и упозоравали власт и народ на тајно дјеловање и непримјетно ширење комуниста. Важно је обратити пажњу на генезу и узроке настанка социјализма и комунизма, нарочито због тога што су се том темом много бавили аутори радова које смо проучавали.

Филозофска и социјална мисао Европе првих деценија 19. вијека условљена је једним дубоким преломом. Ријеч је о надама које су биле везане за велику Француску револуцију, као и разочарење у наивни рационалистички и оптимистички поглед на свијет који је посебно владао у 18. вијеку. Тај историјски биланс изазвао је крупан преврат у умовима људи. Прије свега, појавио се низ истакнутих мислилаца као што су: Едмунд Берк (Edmund Burke) у Енглеској, Жозеф де Местр (Joseph de Maistre), Сен-Симон (Claude Henri de Rouvroy, Saint Simon) и Огист Конт (Auguste Comte) у Француској, те Фридрих Хегел (Georg Wilhelm Friedrich Hegel) у Њемачкој, који су једнодушно доказивали да је рационалистички оптимизам 18. вијека лаж (Пери, 2010, стр. 280-321). Из овога се рађа идеја да структура друштва није условљена друштвеним идеалима, већ се условљава његовим економским потребама. Све остале појаве у области друштвеног живота и друштвене идеологије, политичка борба странака, држава и сви облици друштвеног живота, као што су породица, религиозна вјеровања, литература, наука и умјетност само су рефлекс на економску структуру и немају самостално значење, него су фундирани у главном покретачу - економији (материјализму) - (Берђајев, 1938, стр. 145-156). 
На крају ћемо, уз све већ наведено, приказати и шта су то аутори који су се бавили овим питањем савјетовали да би се ширење и напредовање комунизма зауставило. Изразито су значајни критика и контранапад који се дају ишчитати у периодици обрађених српских црквених часописа. У њима предњаче савјети држави, институцијама, Цркви и народу, али се осјећа и жаљење због равнодушности и незаинтересованости одређених организација и друштава за активнију борбу против комунизма, што свакако доприноси његовој лакшој организацији и ширењу. Комунистичка машинерија била је добро уједињена, сваки члан комитерне вршио је своју обавезу како би се наука проширила на што већи број људи.

\section{СОЦИЈАЛИЗАМ И КОМУНИЗАМ}

Нећемо овдје подробно обрађивати сложен проблем односа социјализма и комунизма, те њихове сличности или разлике које су се с временом појављивале и које имају запажено мјесто у литератури тог периода (Пашев, 1938, стр. 119-120). Међутим, потребно је, због нашег рада, утврдити како су аутори поменутих црквених часописа одређивали социјализам и комунизам. Нарочито због тога што су се ти појмови нашироко користили, пунили књиге и улице, могли да се чују с народних трибина, а према свједочанству часописа, били чак и најкарактеристичније црте тог времена (Тарајев, 1940, стр. 96112; Спекторски, 1940, стр. 329-335; Серђукова, 1936, стр. 416-429).

Мада је постојала одређена пометња у дефинисању ових сложених појмова у српским црквеним часописима, можемо рећи да су писци дали задовољавајуће објашњење. Социјализам је добро описан у сљедећим ријечима:

\footnotetext{
„Социјализам се час јавља у специфичном виду синдикализма, час се спаја са разним врстама етатизма, час ступа у везу чак и са из основа туђим начелима - национализмом и хришћанством [...]. Али, узет у својој суштини, он се логички супротставља сваком другом филозофском схватању живота, морала и човека, а тим пре свакој позитивној религији, сваком мистичком откровењу” (Серђукова, 1936, стр. 416).
}

Познато нам је да су социјализам исповиједали и бољшевици у Русији, као и њима супротстављени сљедбеници Хитлера у нацистичкој Њемачкој, те раднички идеолози у демократским земљама, па чак и они који су поистовјећивали социјализам с хришћанством, постављајући Христа као првог социјалисту, а хришћанство фундаментом социјализма (Спекторски, 1940, стр. 329-335).

Сходно реченоме, разлика између социјализма и комунизма није у принципима којима се они воде, него само у границама до којих се иде у њиховом примјењивању, као и у методама њиховог про- 
вођења. Занимљиво је поређење социјализма с капитализмом и комунизмом, гдје се каже да социјализам неминовно води комунизму као својој најчистијој и најдосљеднијој форми, док је, с друге стране, везан за дегенеративне облике екстремног капитализма. Екстремни капитализам, који концентрише уједно и политичку и социјалну економску власт, дјелује на појединце у истом смислу као и социјализам:

\begin{abstract}
„Исти је поглед на човека, који није ништа друго до незнатан шраф у џиновској машинерији; исти је став према својини, чије управљање припада маломе броју - зар није свеједно страначких вођа или економских диктатора? - иста пролетаризација маса, рационализација и механизација рада, нивелисање моралног и културног нивоа заједно са стандардизованим серијама ствари, разонода, уживања" (Серђукова, 1936, стр. 418-419).
\end{abstract}

Капиталистичко друштво је диференцирано, класно, и та диференцијација почива на економској подлози, док је социјалистичко, а тим прије и комунистичко друштво бескласно, нивелисано, и то се нивелисање заснива на економском мјерилу. Иако је структура различита, основ је исти - материјална ознака карактерише човјека и опредјељује однос према њему. Разлика је само у томе што се у једном случају санкционише неједнакост, која се у другом случају пориче ради свеопштег изједначења. Схватање друштва има исти карактер, атомистички и механички, јер се јединке које га сачињавају не разликују по каквоћи, него једино по квалитету, квантитету и броју материјалних добара. Социјализам, као и његов екстрем - комунизам, као и његов родитељ, али и супарник - капитализам - способан је да се креће само у једном плану, и то економском (Маринковић, 1939, стр. 5-8).

\title{
ОРГАНИЗАЦИЈА, ШИРЕЊЕ И ДЈЕЛОВАЬЕ КОМУНИЗМА
}

Као што је у самом наслову назначено, овдје ће више бити ријечи о организацији, ширењу, као и (тајном) дјеловању комунизма. Мада је о овоме доста писано, примјећујемо да је до тога дошло релативно касно. Први рад који обрађује ово питање писан је тек 1928. године, следећи 1933, онда један 1935, три 1936, један 1937. и на крају два рада 1939. године. ${ }^{2}$

\footnotetext{
2 Занимљиво је примијетити да се у српској црквеној периодици до 1928. године не појављује ниједан рад који конкретно обрађује нашу тему. Познато је да је Комунистичка партија Југославије (Социјалистичка радничка партија (комуниста)) основана 1919, а забрањена 1921. године (више о овоме видјети: Морача, Стојановић, 1979, стр. 16-37).
} 
Већ 1919. године, међу народом, а највише међу студентима, користећи оскудицу, економске проблеме, несређеност политичких и привредних прилика у земљи, за шта Први свјетски рат носи највећу одговорност, почињу да дјелују разне политичке групе. ${ }^{3}$ За разлику од ширења социјализма прије Првог свјетског рата, комунизам се послије Великог рата шири преко добро организованих комунистичких центара који су под директном јурисдикцијом највиших партизанских органа у земљи и иностранству. Цјелокупна комунистичка пропаганда управља се из Москве преко Треће интернационале, коју свестрано потпомаже Совјетска влада (М. Јовановић, 1936, стр. 51).

Комунистички агитатори фанатички се, јавно или тајно, боре да придобију што више присталица. Да би то успјели, комунизам покушава да сруши религију и морал, који као два стожера успјешно пркосе комунизму и материјализму:

„И комунизам и религија желе да изграде и изграђују човјека, али не са истим средствима и методама. За материјализам човјек је бездуховна ствар, за религију он је син Божји, одуховљено биће [...]. Комунисти да би дошли до побједе морају сконцентрисати снагу на рушење, односно ослобађање човјека од службе Богу и Божанском" (Ј. Јовановић, 1939, стр. 60).

Да је стање лоше у Русији, те да комунисти покушавају и у Краљевини CXС/Југославији тајно, непрестаним лажима и преварама продријети међу власт и народ - свједочи нам писмо митрополита Антонија Храповицког архиепископу кентерберијском Вилијаму (William Cosmo Gordon Lang) - (Храповицки, 1930, стр. 76). Добро организована, с вјерним члановима комитерне инфилтрираним на сва могућа мјеста, дистрибуирајући мноштво књига и брошура рушилачке садржине, комунистичка организација биљежи одличне резултате. Вјешто се кријући под маском демократизма, пријатеља и доброжелитеља народа, лако искориштава сваку прилику и незгоду као што су незадовољство, незапосленост радника, породичне неслоге, смртни случајеви и др.

Карел Чапек, свјестан стања које је владало у капиталистичком друштву економски нестабилне државе с много незапослених, доста незадовољних, мучених великом биједом и невољама, пита се да ли је комунизам тај који ће, носећи заставу револуције, поправити тешко

\footnotetext{
${ }^{3}$ Студенти социјалисти су априла 1919. године, подстакнути конгресом уједињења социјалистичких партија у Београду, те инспирисани револуционарним догађајима у Русији, Њемачкој и Мађарској, промијенили име у Клуб студената комуниста и активно учествовали у оснивању Савеза комунистичке омладине Југославије 10. октобра 1919. године у Загребу (више о овоме видјети: Бонџић, 2004, стр. 42).
} 
стање, да ли ће, умјесто владања и моћи над народом, донијети мир и помоћ:

„Видео сам беду и невољу тако страшну и неисказану, да сам и на себе сама био огорчен [...]. Буржоазија која не зна или неће овде да помогне, страна ми је; али ми је исто тако стран и комунизам који место помоћи доноси револуцију [...]. Сиротиња, глад, незапосленост нису за комунизам неподношљива невоља, нити срамота, него добро дошла резерва тамних сила, која кипи у гомили бунта и отпора" (Чапек, 1937, стр. 264).

Комунизам тог времена имао је посебно песимистичну црту дјеловања и критиковања свијета и друштва око себе, коју је користио како би потопио владајуће уређење, док се нпр. пролетер - радник тог времена, супротно осјећао. Он крај машине много радосније пјева од директора фабрике:

„Тзв. пролетер по природи је склон скоро веселом и детињском схватању живота; комунистички песимизам и нејасна завист вештачки су му сервирани и то ко зна каквим средствима. Овај импорт очајне натмурености назива се 'васпитање маса за револуцију' или 'јачање класне свести'” (Чапек, 1937, стр. 268)

Физичка и духовна патња човјека (Поповски, 1940, стр. 61) комунизму је служила као једна врста окидача којим је он критиковао буржоазију и капитализам. Ово је била честа тема у великом броју обрађених текстова тог периода (Чапек, 1937, стр. 265-272; Божић, 1928, стр. 1-4; Ј. Јовановић, 1939, стр. 60-66; Тарајев, 1940, стр. 96112).

Многи аутори осуђивали су комунизам због бруталног генерализовања и вјештачког непознавања свијета: „Завист, незнање, принципијелно неповерење - то је душевни свет комунизма; лекарска дијагноза гласила би: патолошки негативизам" (Чапек, 1937, стр. 269). Метода дјеловања комунизма јесте активно ширење неспоразума у покушају да се човјек разбије на комаде, отуђи од неистомишљеника, заведе разним обећањима и на крају влада над њим. Капиталиста и пролетер претворени су у апстракције, у грубе симболичке фигуре, и у тој вулгарној поларизацији све оно што је потребно пролетеру проглашава се за добро, док жеље, потребе и жудње првих за природно зло:

„Захтеви пролетера, па било и на штету заједнице и њеног економског напретка - јесу 'добро'; тражења капиталисте, па било и разумна и корисна по само предузеће, јесу зло; жудње пролетера - добро, жеље капиталисте - зло, стомак пролетера - добро, апетит капиталисте - зло итд." (Серђукова, 1936, стр. 417). 
Необавијештеном народу говорило се да ће се, када комунизам завлада, постићи она слобода, она правда, једном ријечју, она срећа која већ господари у Русији посредством револуције и мржње. Радник неће радити колико је радио до сада, умјесто сељака, радиће машина, пензионер ће имати вишу плату, ђак бесплатно школовање дакле, за свакога лијепа ријеч која се примала без резерве и контроле. Обичан народ, према свему судећи, није знао каква је ситуација у Русији, није знао да она више није што је кроз историју била. Још је постојала одређена врста култа према Русији, који је рађао неоспорну љубав према њој, тој великој грани на словенском стаблу:

„У садашње вријеме када је потребна узајамна помоћ, када се обнављају и наново стварају везе са другим народима за одбрану својих права, мисао нашега народа је упућена на Русију и руски народ. Проста маса не може да вјерује да она није више она света 'матушка' Русија, која је била понос Словенства. Не може да вјерује да она више није гаранција као некада и да је земља крви и ужаса” (Ј. Јовановић, 1939, стр. 64).

У већ поменутом писму митрополита Антонија, првојерарх Руске заграничне цркве жали за неизмјерним страдањима која му сатиру несрећну домовину, која, може бити, већ стоји на прагу своје пропасти (Храповицки, 1930, стр. 75). Међутим, комунистички социјализам није била руска мисао, него је пренијета споља и страшним и крвавим насиљем накалемљена руском народу. Русија тог времена примјер је како диктатура пролетеријата, материјализам, атеизам, као и идеја класне борбе која је дигнута на степен фанатичке догме, не доносе „рај на земљи” (Спориш, 1937, стр. 78; Н.Н., 1940, стр. 15). Револуција у Русији успјешно је проведена зато што су комунисти успјели да на ирационалну, економски потпуно нецјелисходну страст народних маса накалеме и с њим стопе фанатички (комунистички) поглед на свијет. Управо на ово су упозоравали и баш ово се спремало двадесетих и тридесетих година прошлог вијека у Краљевини СХС/Југославији:

„Руска револуција је класични историјски пример како дубоко ирационалне страсти неекономског реда, када се здруже са идеолошком страшћу вођа, могу довести до огромних и недогледних историјских последица" (Франк, 1935, стр. 10).

Као поље мисионарења, комунизам је изабрао и омладину, ученике и студенте. У њима су видјели младе нараштаје које треба привући и касније искористити за своје циљеве. Запажену улогу у развоју комунистичке организације и значајан политички фактор револуционарног студентског покрета на Београдском универзитету одиграла је управо Комунистичка студентска фракција (Костуфра). Њу су сачињавали сви комунисти на Универзитету, а на челу исте 
налазио се секретаријат који је заказивао састанке и руководио њеним радом (Васић, 1977, стр. 244).

Временом је настала потреба за легалном студентском организацијом која би на цијелом Универзитету успјела сакупити не само све комунисте него и остале, демократски оријентисане студенте. Ово питање постало је још актуелније послије маја 1932. године, када су договори о заједничкој платформи са другим студентским групама, иницирани од стране студената комуниста, пропали. Због тога су, на приједлог студената комуниста, године 1933. основана факултетска вијећа студената - легална руководства на појединим факултетима. Њихов задатак био је јачање студентског покрета, усмјеравање студентских акција и рад на окупљању и активирању свих демократски оријентисаних студената. Основано је и Централно вијеће студената, које је представљало легално оперативно руководство цијелог студентског покрета на Универзитету (Дамјановић, 1974, стр. 135-145).

Универзитети су били привлачни за дјеловање комунистичке организације због велике концентрације омладине различитог социјалног састава, пуне незадовољства, енергије и младалачког бунта. С друге стране, вријеме диктатуре, политичке репресије, економске кризе, државне нестабилности и националног трвења потхрањивало је незадовољство и погодовало дјеловању партије (Бонџић, 2004, стр. 44).

„Тешке околности једне осјетне групе наших студената и ученика у опште, који се школују под неповољним условима, доводи до потпомагања комунизма", каже Јовановић и наставља: „Они се интересују проблемима живота [...]. Разочарани у правду, заборављају на школовање, на своју будућност, прилазе комунизму, вјерујући у његове 'идеале' и обећања и агитују за ново друштвено формирање на комунистичким основама" (Ј. Јовановић, 1939, стр. 65-66).

Партија је користила интелектуалну незрелост оних који су још млади и без могућности и способности слободног и зрелог расуђивања о замршеним и тешким питањима данашњице.

Један од главних извора комунистичке пропаганде били су сами наставници, комунисти. Њих је, истина, било мало, али сасвим довољно да клицу комунистичког рушилачког бијеса усаде у младе душе ученика и студената. Ти наставници били су врло агресивни, лако и просто, чак неометано излагали су ученике свом фанатизму, цинизму и комунистичким утопијама. Није био риједак случај да се код ових наставника - агитатора школски час претвори у комунистички збор (Слијепчевић, 1937, стр. 22-24). Ауторитету наставника, рушилачкој доктрини која дражи ниске нагоне, намјештеном заносу, голицању сујете, подлијежу, на крају, слаби и неискусни ученици. Такав наставник организује ђачке дружине које касније постају пра- 
ва сјеменишта комунизма. Утицајем и ауторитетом наставника у тим ђачким дружинама до изражаја долазе само бољшевизирани ђаци. Ко би од ученика другачије мислио, бивао је исмијан, отјеран и извргнут најгнуснијој тиранији. Ђак би најзад, милом или силом, упао у замку, ушао у организацију, прошао обуку и бивао регрутован као тајни „војник” комунистичке организације (С. К. 1936, стр. 183).

Великог успјеха имали су студенти привржени комунизму током 1934. године, када су успјели да преузму готово сва стручна, културна и друга удружења, чији је број на Универзитету достизао и до 30 истих. Да би сва „освојена” удружења била под једним руководством, студенти комунисти на општестудентском збору 10 . јуна 1934. године образују Акциони одбор стручних студентских удружења, који је у односу на универзитетске власти био репрезентативно, а у односу на студентска удружења руководеће и координационо тијело. „Проширујући својим деловањем руководећу улогу комуниста, од изузетног значаја било је то што је АОССУ имао статус легалног тела, јер се он, као израз снаге студентског покрета, заправо наметнуо и универзитетским властима као признати орган студената и аутентични представник њихових интереса [...]. Дакле, АОССУ, поред свега тога, није деловало одвојено од партијске и скојевске организације нити мимо њихове руководеће улоге", каже Милица Дамјановић и наставља: „, Повезаност се испољава и у томе што су комунисти, чланови Партије и СКОЈ-а, као најактивнији па, према томе, и најутицајнији људи у студентским срединама најчешће, а готово и по правилу, били чланови АОССУ" (Дамјановић, 1974, стр. 324).

Формирањем АОССУ-а, студентски покрет на Београдском универзитету улази у нову фазу. Можемо забиљежити рапидан раст комунистички настројених студената. Покрет је почео све више да добија на масовности и револуционарности, тако да слободно можемо рећи да је формирањем АОССУ-а, револуционарни студентски покрет под вођством студената комуниста, доживио свој зенит, рачунајући од времена настанка до 1941. године. На Православном богословском факултету је од 1936. године била активна ћелија АОССУ-а у оквиру Удружења студената Православног богословског факултета (Раковић, 2015, стр. 85). Исто нам свједочи и Милица Дамјановић проучавајући, како она каже, „ретко уредну књигу записника са својих седница", мислећи наравно на записник АОССУ-а (Дамјановић, 1974, 325).

Комунистичко агитовање омладине дешавало се и у средњим школама највише кроз извјесне гутемплерске ложе, које су тако постајале прикривена жаришта комунизма. Идејом трезвености застирала се бољшевичка акција, оно што је незаконито и оно што је у основи било неморално - тада је слободно живљело у једној законитој институцији гутемплерства које је, све више, постајало камуфлажом комунизма (Деврња, 1936, стр. 117). 
Да су се ђаци и студенти налазили између Скиле, с једне, и Харибде, с друге стране, свједочи нам низ објављених чланака који критикују ондашњу дневну штампу, која донедавно није вршила никакав културни утицај на наш народ, али која је, посљедњих година, најревноснији пропагатор крајње љевичарске идеологије. Презадојена комунистичким идејама од почетка до краја - од уводних чланака до најситније репортаже - дневна штампа ствара у ученику диспозицију за марксистички нихилизам. Поред свега, нарочито старијим ученицима, препоручује се популарно научно-природњачко или историјско и социолошко штиво кроз које се намеће материјалистичко схватање свијета и живота, свјесни да ће оно увелико олабавити пређашње идеје и убјеђења, уколико су била стечена у већој или мањој мјери код куће или у школи (М. Јовановић, 1936, стр. 52).

Ђоко Слијепчевић нам свједочи да су постојале „негативне снаге, скривене у недрима цркве; може се рећи да су се развијале све више и више што је време одмицало, под утицајем, делом, левичарске пропаганде [...] под директним утицајем КПЈ” (Слијепчевић, 2002, стр. 10). Историчар Слијепчевић наставља: „Оживљавањем борбене комунистичке акције на Београдском универзитету отпочело је и инфилтрирање комунистичких идеја и међу студентима Православног богословског факултета у Београду. Највећи део оних, који су били оријентисани лево, био је опчињен социјалним моментом у комунистичкој пропаганди. Мањи део их је долазио са већ готовим планом, послат од Партије да би, касније, када постану свештеници, могли да разорно делују унутар цркве. Овакви су, једним делом, слати из гимназија на Православни богословски факултет, а доцније су долазили и из богословија. Богословијама је КПЈ била, пре рата, посветила велику пажњу с циљем да у њима организује своје ћелије" (Слијепчевић, 2002, стр. 11).

Главни расадници комунистичке мисли тог периода и главни дистрибутери пропагандне „црвене” литературе су познате издавачке куће: Нолит, Будућнос, Космос и Политика (Деврња, 1936, стр. 117; С. К., 1936, стр. 183; М. Јовановић, 1936, стр. 52). Оне су годинама засипале земљу комунистичко-марксистичко-атеистичком литературом, бољшевизирајући интелигенцију, провоцирајући и дижући огромне протесте. На полицама књижара све је чешћи Марксов Капитал у издању Космоса, али и разни часописи филовани комунистичком идејом, који су, у тим годинама, ницали као печурке (С. К., 1936, стр. 184).

Осим издавачких кућа и дневне штампе, комунистичку завјеру снују и многи други „културни фактори”. Предавања која су држана на Народном Коларчевом универзитету била су антинационално обојена. Преко комуниста који су успјели себи да изграде одређене 
позиције у друштву и на Универзитету ${ }^{4}$, вршила се проповијед комунистичких или бојкот оних идеја које су биле антикомунистичке, мада таквих, нажалост, није било превише (Ј. Јовановић, 1939, стр. 6566; Деврња, 1936, стр. 117; С. К. 1936, стр. 182).

\section{ПРЕВЕНЦИЈА И БОРБА ПРОТИВ КОМУНИЗМА}

До сада смо писали о настанку и ширењу комунизма. Рекли смо да су били добро организовани, често тајно радили и улагали огромне напоре да би се инфилтрирали у све поре друштва. Сада је вријеме да се боље упознамо с техникама или начинима одбране или превенције од комунизма, које су предлагали, указивали и захтијевали аутори поменутих радова.

Многи писци су сматрали да је хришћанство, ако не у потпуности, онда добрим дијелом одговорно за настанак комунизма. Берђајев пише:

„За хришћане комунизам треба да има нарочити значај, - он је израз и знак неиспуњене дужности и неостварене хришћанске задаће [...]. Хришћанско 'добро' постало је одвећ условно - реторски, а остварење неких елемената тога 'добра', прокламованог у идеји, али врло рђаво оствареног у пракси, завршава се страховитом реакцијом против хришћанства. Грех и нискост хришћана, тачније лажних хришћана заклонио је и замрачио блиставу светлост хришћанског откривења" (Берђајев, 1938, стр. 145-156).

„Како је дошло до тога”, пита Спекторски, „да огроман број радника пође за њима?”, и одговара:

„Није оно криво, јер је мало посвећено, препуштено само себи и напуштено од оних, који би могли и морали ширити код њега здраве социјалне појмове. Криви су они који се сматрају за интелектуалну елиту само зато што поричу ма какву етику и сматрају цинизам за врхунац духовне културе. Криви су и

\footnotetext{
${ }^{4}$ Већ 1929. године (подсјећамо да је влада Краљевине СХC 30. децембра 1920. године декретом „Обзнана” забранила рад Комунистичке партије Југославије и прокомунистичких синдиката, послије чега је КПЈ остао у илегали и доживљавао темељне промјене, унутрашње кризе и борбе фракција), на Универзитету је дјеловало око 20 студената комуниста и скојеваца. Број студената до 1932. године расте на 40 и у овом периоду, преко Комунистичке студентске фракције (Костуфра), сва студентска стјецишта, факултети, домови, мензе и разна студентска удружења постају центри комунистичке дјелатности. Према ријечима Драгомира Бонџића: „Писање прорежимске штампе нам говори да су КПЈ и СКОЈ заиста тридесетих година доминирали на Универзитету и руководили радом студентских организација. Оне су том раду давале изразито политички, идеолошки, антидржавни карактер, што им је и био главни циљ” (Бонџић, 2004, стр. 42-45).
} 
они који се сматрају за хришћане и не воде рачуна о томе, колико дужности и одговорности налаже свакоме име хришћанина" (Спекторски, 1940, стр. 335).

Међутим, иако добар дио аутора критикује и тренутно стање хришћанства, већина их види кривце у тзв. хришћанима и хришћанству. Није Христова личност изгубила своју фасцинацију и помрачила свој свијетао ореол, већ су то учинили људи који се називају хришћанима, а то нису (Пашев, 1938, стр. 119).

Критике нису биле упућене само на рачун „млаког” хришћанства, јер радови говоре и о родитељском дому, школи, друштву, литератури и држави:

„Рад на придобијању чланова који ће бити достојни носиоци имена син Божји занемарен је. Ни родитељски дом, ни школа, ни друштво, ни они који имају за задатак да проповиједају Христову науку не врше свој посао онако како треба и колико треба. То искоришћавају комунисти вјештим пропагандама и перфидним лицемјерством [...]. Најзад да напоменем да се код нас шири комунизам и због слабе, готово никакве противпропаганде. На народним универзитетима не чују се ријечи против комунизма и човјеку изгледа као да се нико не смије ухватити у коштац са њим. Још се понешто чује са царских двери, па и то није Бог зна на висини. Такође и литература против комунизма ријетка је, штура и сиромашна, ако није преведена са страних језика" (Ј. Јовановић, 1939, стр. 61-62).

Стиче се утисак да нико није био на висини задатка и да је остајало много мјеста за евентуалне противпропагандне акције.

Многи аутори позивали су Цркву да „озбиљније и одлучније но икад досад” (М. Јовановић, 1936, стр. 56) крене у помоћ, посебно народној омладини коју су раздирале савремене идејне супротности, духовно беспуће и социјална биједа. Она је требала својим најбољим и најидеалнијим силама, знањем, не више само ријечима него и дјелима, јеванђелски кренути у борбу против комунизма (Н. Н. 1933, стр. 59-60; Ј. Јовановић, 1939, стр. 61-62; Спекторски, 1940, стр. 333; Слијепчевић, 1937, стр. 24).

Посебно су се обраћали просвјети и тражили од ње ангажованост, јер су схватили какав се потенцијал крије у њима у борби против комунизма. Тако Јовановић каже:

„Поуздана идејна оријентација самих наставника и што боља обавештеност њихова о свим питањима која се постављају данашњој омладини, широк и ванстраначки национализам и културно-социјална активност међу омладином и народом ван школе, примереност у животу, у спреми и раду, правилан и многостран васпитни контакт са ученицима, знатно ће допринети да се спречи сваки успех нежељених утицаја" (М. Јовановић, 1936, стр. 56). 
Неки су занимљиво савјетовали да се, као што су то чинили римокатолици са својих говорница, царских двери, часописа и посебних студија, и Православна црква слично ангажује, али и да се одређен број људи укључи, више сазна и научи о комунизму, како би касније то своје знање даље ширили мисијом антикомунистичке пропаганде. Аутор је увјерен да би комунизам тада опао (Ј. Јовановић, 1939, стр. 66).

Видјели смо да је комунизам представљао велику опасност тог времена. Комунизам је гасио Духа у људима, истискивао је Христа из њихових свијести. Свјетлост се почела гасити у њима, док је очај почео да се јавља. Доктор Ђоко Слијепчевић каже да је:

„Наша дужност да зауставимо та рушења, угасимо пожаре. Разобличимо легенде и у душе људи, духовно опустошених, унесемо светлост истинске правде и љубави. У томе је и најважнији проблем нашег времена” (Слијепчевић, 1937, стр. 24).

\section{ЗАКЉУЧАК}

Може се констатовати да су социјализам и комунизам, као тада нове политичке филозофије, заузели запажено мјесто у српским црквеним часописима између 1920. и 1940. године. Иако су најчешће критиковани, посебно због своје праксе, неки аутори су подржавали њихову идеју, идеју утопистичког социјализма (Мор, 2002; Јагодић, 1936, стр. 76). Супротстављајући се капиталистичком духу, који је сав вишак добара давао капиталисти - власнику, док је радник живио на минимуму, социјализам подиже „револуцију”. Социјалисти су сматрали да су сви једнаки, те да заслужују једнак дио у заради и власништву, посебно у вишку, који сада више не иде капиталисти, јер класно друштво не треба да постоји, него раднику, односно свима једнако. Може се рећи да се ова идеја једнакости, престанак експлоатисања радника и богаћења само једног дијела становништва, обрађеним ауторима чланака чак и свидјела. Међутим, упозоравали су, највише посматрајући стање у Русији, али и из искуства огромног броја људи који су стигли у Краљевину СХС/Југославију због бољшевичке репресије (Пузовић, 2001, стр. 456-457) да је комунизам у теорији можда добар, док је у пракси страшан.

Више смо рекли и о организацији и развоју комунизма, али и Комунистичке партије Југославије, која је највише због наглог ширења и тајног и активног дјеловања била критикована од црквених часописа. Чланови партије показали су велику организацијску снагу у свом дјеловању користећи сваки неспоразум и цијепање као погодно тле за субверзивно дјеловање.

Због тога је велики број радова негативно критиковао појаву комунизма и на овим подручјима. Плашили су се добре организације 
и тајног рада, упозоравали на фаталне посљедице и захтијевали спремање конкретније антикомунистичке одбране. Већина аутора упозоравала је читаоца на погубну материјалистичку филозофију комунизма, која је човјека лишавала личне слободе и морала. Таква идејна поставка, према схватању потписника обрађених радова, срозавала је човјека у религијском, моралном, културном, умјетничком и свим другим видовима (Милосављевић, 1936, стр. 84-86).

На крају, нисмо стекли утисак да су аутори задовољни приступом Цркве, државе, друштва, медија и др. када је у питању борба против комунизма. Осјећамо да је било још много мјеста за успјешан рад који би осујетио њихове планове, док је комунизам добро знао искористити пасивно, незаинтересовано и неактивно стање, које је тада било најзаступљеније.

\section{ЛИТЕРАТУРА}

\section{Извори}

Берђајев, Николај, (1938) Истина и лаж комунизма - прилог за схватање религије комунизма [The Truth and the Lie of the Communism - a Contribution to the understanding of the Communism religion], Светосавље, VII, 4, 145-156.

Божић, Саво, (1928) Свештенство и комунизам [Christianity and Communism], Весник, бр. 18, IX, 1-4;

Деврња, Милутин, (1936) Како се у Београду врбује необавештена омладина за Марксизам [How to Recruit Uninformed Youth to Marxism in Belgrade], Хришћанска мисао, II, 7-8, 117-118.

Јагодић, Здравко, (1936) Утопистички и научни социјализам [Utopian and Scientific Socialism], Хришћанска мисао, II, 5, 76-78.

Јовановић, Ј. (1939) Зашто се код нас шири комунизам [Why Communism is Spreading among us], Пастир, год. 4, 2-3, 60-66.

Јовановић, М. (1936) Поводом комунизма у нашим школама [Regarding Communism in Our Schools], Хришћанско дело, бр. 2, 50-57.

К. С. (1936) Ко заводи нашу децу? [Who is Seducing Our Children?], Хришћанска мисао, II, 12, 182-184.

Маринковић, Живан, (1939) За активнију социјалну делатност наше Цркве [For a More Active Social Activity of Our Church], Хришћанска мисао, I, 5-8.

Милосављевић, Јелена, (1936) Ниче и Маркс - Неколике маргиналије [Nietzsche and Marx - A few Marginal's], Хришћанска мисао, II, 6, 84-86.

Митрополит Антоније Храповицки, (1930) Писмо митрополита Антонија архиепископу кентерберијскому, [A Letter of the Mitropolit Antonio to Archbishop of Canterbury], Гласник, бр. 5, 75-87.

H. Н. (1933) Не треба оклевати [Do Not Hesitate], Гласник, XIV, 4, 59-61.

H.Н. (1940) Две супротне идеологије [Two Opposing Ideologies], Хришћанска мисао, бр. 1-2, 1-5.

Пашев, Г. (1938) Будимо опрезни, јер су времена превртљива [Let's Be Careful, Because Times Are Giddy], Хришћанска мисао, IV, 11, 119-120.

Поповски, П. (1940) Да ли је комунизам остварљив [Is Communism Achievable], Светосавље, IX, бр. 3, 60-64. 
Серђукова, Александра, (1936) Социјализам и хришћанство [Socialism and Christianity], Хришћанско дело, II, 416-425.

Слијепчевић, Ђоко, (1937) Најважнији проблем нашег времена [The Most Important Problem of Our Time], Хришћанска мисао, III, 2, 22-24.

Спекторски, Евгеније, (1940) Хришћанство и социјализам [Christianity and Socialism], Хришћанско дело, VI, 328-335;

Спориш, Л., (1937) Социјализам [Socialism], Хришћанска мисао, III, 5, 78;

Тарајев, М, (1940) Морална трагедија социјализма [The Moral Tragedy of Socialism], Хришћанско дело, VI, 96-112;

Франк, С., (1935) Критика марксизма [Criticism of Marxism], Хришћанска мисао, И, 1, стр. 11-13; 2, стр. 9-11; 3, стр. 10-11; 5-6, стр. 14-16; 7, стр. 12-14;

Чапек, Карел, (1937) Зашто нисам комуниста? [Why Am I Not a Communist?], Хришћанско дело, III, 264-272.

\section{Помоћна литература}

Бонџић, Драгомир, (2004) Београдски универзитет 1944-1952. [University of Belgrade 1944-1952], Београд: Институт за савремену историју.

Васић, Мирољуб, (1977) Револуционарни омладински покрет у Југославији 1929-1994. [Revolutionary Student Movement in Yugoslavia 1929-1994], Београд: Народна књига.

Милица Дамјановић, (1974) Напредни покрет студената Београдског универзитета [Progressive Movement of Students of Belgrade University], Београд: Нолит, 135-145.

Мор, Томас, (2002) Утопија, [Utopia] Београд: Утопија.

Морача, Перо, Стојановић, Станислав, (1979). Комунисти Југославије, [The Communists of Yugoslavia] Београд: Експорт прес.

Пери, Марвин, (2010), Интелектуална историја Европе, [Intellectual History of Europe] Београд: Clio.

Пузовић, Владислав, (2001) Посредовање српског патријарха Варнаве (Росића) у канонском спору између Московске патријаршије и Архијерејског синода Руске заграничне цркве [Mediation of Serbian Patriarch Varnava (Rosić) in the Canonical Dispute between the Moscow Patriarchate and the Archeries Synod of the Russian Orthodox Church], Српска теологија данас, 2, 455-463.

Раковић, Александар, (2015) О несугласицама на Православном богословском факултету (1934-1941) [Disputes in the Orthodox Theological Faculty (1934-1941)], Теолошки погледи, XLVIII, 1, 85.

Слијепчевић, Ђоко, (2002) Историја Српске православне иркве, III [History of Serbian Orthofox Church], Београд: Култура.

Цисарж, Бранко, (1986), Један век периодичне штампе Српске православне иркве [A Century of Periodicals Print of Serbian Orthodox Church], Београд: Свети архијерејски синод Српске православне цркве. 


\title{
SERBIAN CHURCH MAGAZINES ABOUT THE ORGANIZATION OF COMMUNISM, EXPANSION AND OPERATION IN THE KINGDOM OF SHS / YUGOSLAVIA (1920-1940)
}

\author{
Nebojša Malešević \\ University of Belgrad, Orthodox Theological Faculty, Belgrade, Serbia
}

\begin{abstract}
Summary
It can be concluded that both socialism and communism, as the new political philosophy at the time, occupied a special place in Serbian Church magazines from 1920th to 1940th. Although most often criticized, especially because of their practice, some authors have supported their idea, the idea of utopian socialism (more on this subject see: Mor, 2002 Jagodić, 1936, pg. 76). By resisting the capitalist spirit, which gave all its excess of goods to the capitalist-owner, while the worker had minimum rights, socialism raised "revolution". Socialists believed that all people are equal and that everyone deserves an equal share in earnings and property, especially when it comes to the excess of goods, which is now no longer going to the capitalists, because a class society should not exist, but to the worker, i.e. to everyone it goes equally. It can be said that this idea of equality, termination of workers exploitation and enrichment of only one part of the population, the authors' of the covered articles liked this idea. However, they warned people, mostly by watching the situation in Russia, but also from personal experience of the huge number of people who arrived in the Kingdom of SHS / Yugoslavia because of Bolshevik repression (more on this subject see: Puzović, 2001, pg. 456-457) that Communism in theory may be good, while in practice is horrifying. We said more about the organization and development of communism and also about the Communist Party of Yugoslavia, which was mainly criticized due to the rapid spread of the secret and active work by the Church magazines. Party members showed great organizational strength in its activity using any misunderstanding and splitting as a fertile ground for subversive activity. Therefore, a large number of works negatively criticized the emergence of communism also in these areas. They were afraid of organizations and covert operations, and they also warned on the fatal consequences, and demanded better preparation of anti-communist defense. A large number of authors warned the readers of to destructive materialistic philosophy of communism, which deprived the man of its personal freedom and morality. Such ideological setting, in the mind of the signatories of the works that we covered, downgraded the man in the religious, moral, cultural, artistic and in other forms (more on this subject see: Milosavljevic, 1936, 84-86). Finally, we have an impression that the authors are satisfied with the approach of church, society, media and etc, when it comes to the fight against communism. We believe that there were many places for a successful operation that would prevent their plans, while communism knew how to take advantage of the passive, indifferent and inactive state, which was at the time the most represented.
\end{abstract}

